\title{
Manajemen Kinerja dalam Kerangka Flexible Working Arrangement: Pengalaman dari pelaksanaan WFH, Cascading Target Kinerja Harian
}

\author{
Performance Management for Flexible Working Arrangement: experience \\ from Work From Home Implementation, Measuring of Daily Performance
}

\author{
Ladiatno Samsara \\ Lembaga Administrasi Negara, Republik Indonesia \\ E-mail: samsaraladiatno11@gmail.com
}

\begin{abstract}
The implementation of the Flexible Working Arrangement (FWA) gets valuable lessons from the implementation of Work From Home (WFH). The implementation of WFH provides an overview of several aspect that need to be improved. Such as performance management. Performance management managing performance from planning to evaluation. In performance management there are performance targets and performance appraisal. In the FWA framework, performance targets should be measured from daily performance. Therefore, this paper will describe cascading performance targets down to daily performance. In addition, it also describes the competency needs of employees to be able to set detailed and measurable performance targets. This paper uses a qualitative descriptive technique by emphasizing the flexibility of discussion using a review of various literature. The results of this study show that in the implementation of FWA, the aspect of performance planning is the key. Employee performance planning is prepared down to a more detailed stage, namely daily performance. Daily performance becomes a measure of employee productivity when implementing $F W A$.
\end{abstract}

Keywords: Flexible Working Arrangement, Performance Management, Performance Planning

\begin{abstract}
Abstrak
Implementasi Flexible Working Arrangement (FWA) mendapatka pembelajaran berharga dari implementasi Work From Home (WFH). Pelaksanaan WFH memberikan gambaran beberapa aspek yang perlu ditingkatkan. Salah satunya manajemen kinerja. Manajemen kinerja mengelola kinerja dari perencanaan sampai evaluasi. Dalam manajemen kinerja terdapat target kinerja dan penilaian kinerja. Dalam kerangka FWA, target kinerja harus diukur sampai ke kinerja harian. Oleh sebab itu, dalam tulisan ini akan digambarkan cascading target kinerja sampai ke kinerja harian. Selain itu juga digambarkan kebutuhan kompetensi pegawai untuk dpaat Menyusun target kinerja yang detail dan terukur. Tulisan
\end{abstract}




\section{Samsara: " Manajemen Kinerja dalam Kerangka Flexible Working Arrangement: Pengalaman dari pelaksanaan WFH, Cascading Target Kinerja Harian"}

ini menggunakan teknis deskriptif kualitatif dengan menekankan pada keleluasaan pembahasan menggunakan tinjauan berbagai literatur. Hasil penelitian ini melihat bahwa dalam pelaksanaan FWA, aspek perencanaan kinerja menjadi kunci. Perencanaan kinerja pegawai disusun sampai ke tahap yang lebih detail yaitu kinerja harian. Kinerja harian menjadi ukuran produktivitas pegawai Ketika implementasi FWA.

Kata kunci: Flexible Working Arrangement, Manajemen Kinerja, Perencanaan Kinerja

\section{Pendahuluan}

Flexible Working Arrangement (FWA) dalam penelitian Hada, Fanggidae dan Nursiani dapat membantu menyeimbangkan pekerjaan dan kehidupan pribadi pegawai (Hada,2020). Shagvaliyeva \& Yazdanifard (2014) menyebutkan bahwa Flexible Working Hours mengurangi stress kerja pegawai serta meningkatkan produktivitas pegawai. FWA di sektor publik belum diimplementasikan namun sudah diberikan pengalaman untuk mengelola FWA. Work From Home (WFH) menjadi alternatif implementasi FWA. Akan tetapi, tujuan WFH bukan sebagai bagian untuk menyeimbangkan pekerjaan dengan kehiduan sosial. Melainkan lebih untuk mengurangi penyebaran virus Covid-19.

Dalam implementasinya, WFH belum sepenuhnya ideal. Publikasi Kementerian Pendayagunaan Aparatur Negara dan Reformasi Birokrasi (Kemenpan RB) menunjukkan bahwa pelaksanaan Work From Home (WFH) yang berlangsung sejak Bulan Maret sampai saat ini masih menunjukkan banyak kekurangan. Survey Kemenpan RB tersebut melihat bahwa mayoritas responden menyatakan bahwa ketersediaan jaringan internet belum sepenuhnya maksimal. Sebanyak $51,70 \%$ dari 75.348 responden menyatakan hal tersebut (Bahan Paparan Kemenpan RB mengenai Arah Kebijakan Mengenai Manajemen ASN Di Masa Pandemi Covid-19, 2020).

Selain itu, pelaksanaan WFH hanya memindahkan pekerjaan dari kantor ke rumah tanpa mengurangi formalisasi pelaksanaan pekerjaan. Salah satunya terkait jam bekerja, pelaksanaan WFH masih memberlakukan jam kerja 8 to 16 dengan 5 hari kerja. Sedangkan untuk instansi yang menerapkan 6 hari kerja, jam kerja menyesuaikan.

Selain itu, formalisasi absensi kehadiran juga masih diberlakukan. Absensi Ketika pelaksanaan WFH juga masih sama dengan absensi kehadiran di kantor. Masing-masing instansi memberlakukan dua kali absensi. Bahkan di beberapa instansi juga memberlakukan tiga kali absensi. Satu absensi lainnya dilakukan di jam istirahat. 


\section{Jejaring Administrasi Publik, Vol. 13, No. 1, 2021, hal 1-17}

Selain itu, pelaksanaan WFH juga memiliki kendala dalam hal operasional. Salah satunya kebutuhan teknologi informasi untuk mendukung pekerjaan. Hal ini juga yang menjadi kendala. Tidak semua pegawai, yang instansinya menerapkan kebijakan WFH, memiliki dukungan fasilitas teknologi informasi seperti internet, HP dan komputer.

Selain itu, implementasi WFH yang dijadikan kebijakan darurat dalam penanggulangan pandemic Covid-19 belum sepenuhnya diikuti dengan penyesuaian kebijakan lain. Misalnya beban kerja. Beban kerja jabatan belum menyesuaikan dengan kebutuhan pekerjaan yang dilakukan secara remote dengan bantuan teknologi. Misalnya untuk jabatan pelaksana administrasi keuangan, deskripsi pekerjaan masih dilakukan dengan menggunakan computer PC. Padahal, selama pelaksanaan WFH dekripsi pekerjaan tersebut berubah, bukan menggunakan PC melainkan perangkat lain.

Perbedaan deskripsi pekerjaan tersebut membuat pelaksanaan pekerjaan terhambat. Setidaknya untuk beberapa jabatan, selama pelaksanaan WFH, tidak bisa diimplementasikan karena terkendala perangkat teknologi informasi. Salah satu hal diatas, berdasarkan survey yang dilakukan Kementerian Pendayagunaan Aparatur Negara dan Reformasi Birokrasi (Kemenpan RB), mayoritas pegawai tidak menghendaki pelaksanaan WFH Ketika infrastruktur teknologi informasi belum tersedia dengan baik. Pegawai tidak bisa bekerja optimal karena terkendala sarana dan prasarana teknologi. Hal ini menyebabkan kinerja pegawai tidak bisa optimal. Pegawia tidak bisa menyelesaikan pekerjaan bukan hanya karena tidak mampu untuk melakukan pekerjaan. Namun, pekerjaan yang dilakukan sangat terkait dengan sarana dan prasarana teknologi.

Pelaksanaan WFH juga memiliki permasalahan lain. Salah satunya ukuran kinerja yang belum sepenuhnya jelas. Sehingga target kinerja harian pegawai, umumnya belum dapat terpantau secara maksimal. Terdapat dua permasalahan utama terkait target kinerja yang belum bisa secara optimal dapat terpenuhi. Pertama, pekerjaan yang memang tidak bisa dilakukan dengan WFH. Artinya, seluruh pekerjaan harus dikerjakan di kantor. Biasanya terkait dengan pekerjaan fisik. Kedua, ukuran kinerja belum sepenuhnya optimal dan terbagi habis pada seluruh jabatan yang terdapat di setiap unit kerja. Sehingga, pegawai belum mengetahui pekerjaan harian masing-masing.

Dua hal ini yang menjadi perhatian. Penyusunan target kinerja yang terdapat di dalam manajemen kinerja menjadi sebuah permasalahan yang perlu dijabarkan secara detil agar Ketika implementasi Flexible Working Arrangement (FWA) dapat berjalan secara optimal. Namun, disisi lain, dalam survey Kemenpan RB juga, ditemukan bahwa pelaksanaan WFH mendapatkan dukungan dari responden karena bisa memiliki waktu luang lebih banyak. 
Samsara: " Manajemen Kinerja dalam Kerangka Flexible Working Arrangement: Pengalaman dari pelaksanaan WFH, Cascading Target Kinerja Harian"

Sebanyak 62,30\% pegawai dari 75.348 responden menyatakan demikian. Artinya, dalam arti sederhana, pelaksanaan WFH bisa dapat mewakili sedikit konsep pelaksanaan WFA. Akan tetapi, perlu banyak penguatan didalamnya. FWA dipahami sebagai pemberian berbagai opsi pelaksanaan pekerjaan misalnya tempat dan waktu. salah satunya menekankan pada keseimbangan antara beban kerja dengan kehidupan sosial pegawai. Sehingga, manajemen kinerja pegawai diatur sedemikian rupa agar pegawai dapat membagi waktu secara berimbang antara kebutuhan pekerjaan dengan kebutuhan sosial dan keluarga.

Penelitian ini mencoba untuk menjelaskan manajemen kinerja pegawai untuk mempersiapkan FWA berkaca dari pengalaman pelaksanaan WFH era Pandemi Covid-19. Metode penelitian deskriptif kualitatif menjadi pilihan untuk menjelaskan konsep manajemen kinerja dan alternatif pilihan manajemen kinerja untuk mempersiapkan FWA. Pembahasan dilakukan dengan melihat berbagai literatur baik itu hasil riset terdahulu, referensi yang membahas terkait manajemen kinerja dan FWA serta berbagai peraturan perundangan tentang manajemen kinerja.

\section{Manajemen Sumber Daya Manusia}

Marwansyah menyatakan sumber daya manusia merupakan pendayagunaan sumber daya manusia di dalam organisasi yang dilakukan melalui fungsi perencanaan sumber daya manusia, rekrutmen dan seleksi, pengembangan sumber daya manusia, perencanaan dan pengembangan karir, pemberian kompensasi dan kesejahteraan, keselamatan dan Kesehatan kerja serta hubungan industrial (Marwansyah dalam samsuni, 2017).

Lebih lanjut, Boxall dan Purcel (2000) dalam Osibanjo \& Adeniji (2012) menyatakan Manajemen Sumber Daya Manusia termasuk didalamnya segala sesuatu yang berhubungan dengan pegawai Ketika berhubungan dnegan perusahaan. Diantaranya terkait kontrak kerja antara pegawai dengan perusahaan. Secara sederhana siklus dari manajemen sumber daya manusia seperti gambar dibawah ini: 


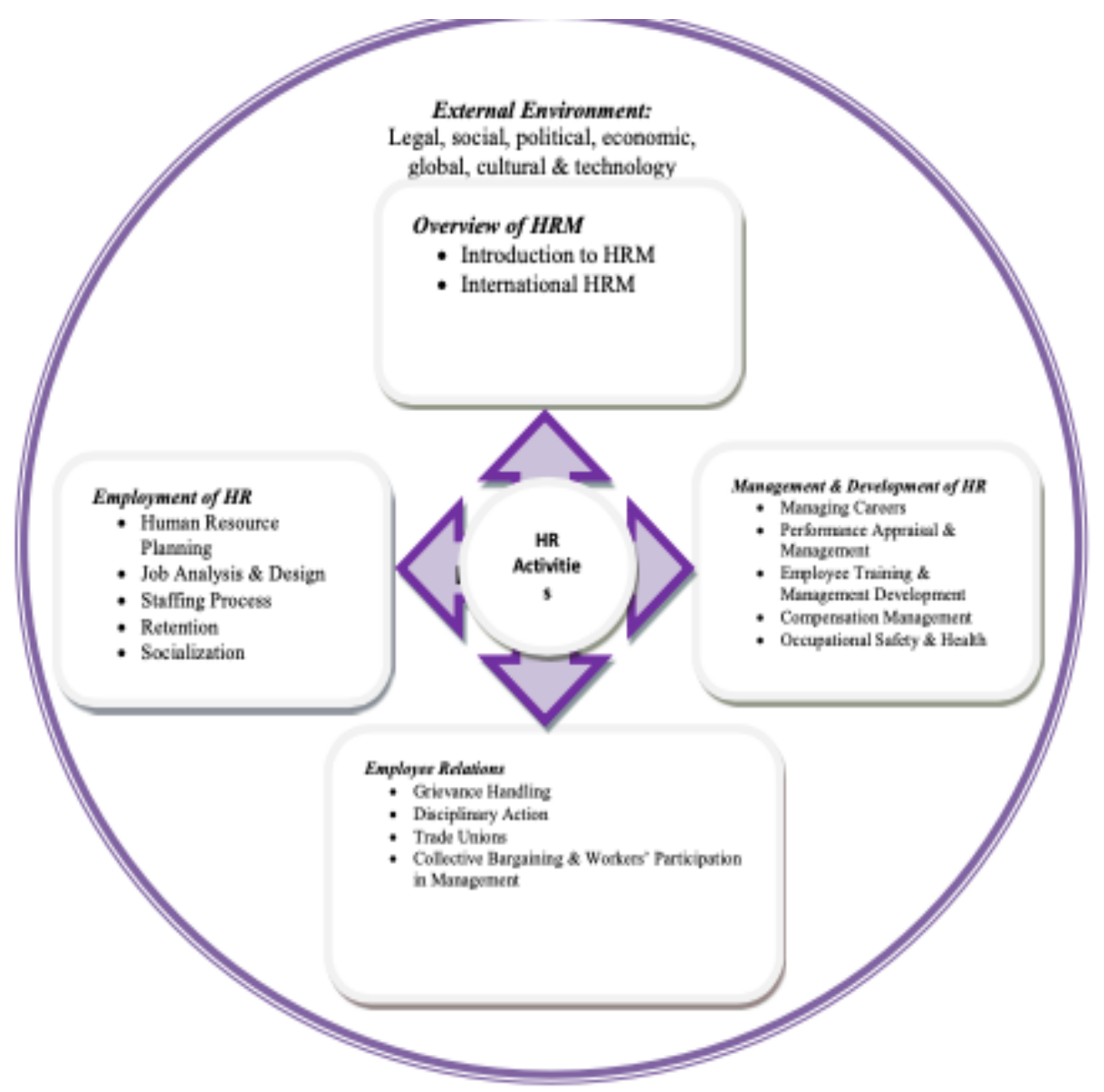

Gambar 1

Siklus Manajemen Sumber Daya Manusia

Sumber: Mathis \& Jackson (2006) dalam Osibanjo \& Adeniji (2012)

\section{Manajemen Aparatur Sipil Negara}

Manajemen ASN diatur dalam Undang-Undang No. 5 Tahun 2014 tentang Aparatur Sipil Negara (ASN). Dalam undang-undang tersebut, ASN dibagi menjadi dua yaitu Pegawai Negeri Sipil (PNS) dan Pegawai Pemerintah dengan Perjanjian Kerja (PPPK). PNS adalah warga negara Indonesia yang memenuhi syarat tertentu, diangkat sebagai pegawai ASN secara tetap oleh pejabat pembina kepegawaian untuk menduduki jabatan pemerintahan. Sedangkan PPPK adalah warga negara Indonesia yang meneuhi syarat tertentu, yang diangkat berdasarkan perjanjian kerja untuk jangka waktu tertentu dalam rangka melaksanakan tugas pemerintahan (UU No.5 Tahun 2014). 


\section{Samsara: " Manajemen Kinerja dalam Kerangka Flexible Working Arrangement:}

Pengalaman dari pelaksanaan WFH, Cascading Target Kinerja Harian"

Pengaturan mengenai teknis manajemen PNS maupun manajemen PPPK diatur dengan Peraturan Pemerintah. Peraturan Pemerintah No.11 Tahun 17 (PP No.11 Tahun 2017) tentang Manajemen PNS menjadi pedoman bagi PNS. Dalam PP No.11 Tahun 2017 disebutkan bahwa Manajemen PNS merupakan pengelolaan PNS untuk menghasilkan PNS yang profesional, memiliki nilai dasar, etika profesi, bebas dari intervensi politik, bersih dari praktik korupsi, kolusi dan nepotisme. Artinya, manajemen PNS merupakan sebuah usaha terstruktur untuk mewujudkan PNS yang profesional.

Dalam manajemen PNS lingkup pengaturan diantaranya penyusunan dan penetapan kebutuhan, pengadaan pegawai, pangkat dan jabatan, pengembangan karir, pola karir, promosi, mutase, penilaian kinerja, penggajian dan tunjangan, penghargaan, disiplin, pemberhentian, jaminan pension dan jaminan hari tua dan perlindungan. Keseluruhan lingkup ini terdapat dalam manajemen sumber daya manusia.

Sedangkan untuk manajemen PPPK diatur dnegan Peraturan Pemerintah No. 49 Tahun 2018 (PP No.49 Tahun 2018) tentang Pegawai Pemerintah dengan perjanjian kerja. PP ini menjadi pedoman dalam manajemen PPPK. Manajemen PPPK merupakan pengelolaan pegawai pemerintah dengan perjanjian kerja untuk menghasilkan pegawai pemerintah dengan perjanjian kerja yang professional, memiliki nilai dasar, etika profesi, bebas dari intervensi politik, bersih dari praktik korupsi, kolusi dan neoptisme.

Manajemen PPPK meliputi penetapan kebutuhan, pengadaan, penilaian kinerja, penggajian dan tunjangan, pengembangan kompetensi, pemberian penghargaan, disiplin, pemutusan hubungan perjanjian kerja dan perlindungan. Lingkup pengaturan manajemen PPPK sejalan dengan pola manajemen sumber daya manusia, mulai dari perencanaan sampai pemberhentian.

Namun, dalam pengelolaan manajemen PNS dan PPPK, terdapat perbedaan yaitu apabila PNS mendapatkan kesempatan untuk pensiun, PPPK terdapat pemutusan hubungan kerja. Artinya PPPK sewaktu-waktu dapat diputus hubungan kerja oleh instansi pemberi kerja dengan berbagai macam pertimbangan. Salah satunya terkait dengan kinerja. Dalam manajemen PNS maupun PPPK terdapat penilaian kinerja. Penilaian kinerja merupakan bagian akhir dari manajemen kinerja. Dimana penilaian kinerja merupakan realisasi dari target kinerja yang telah direncanakan.

\section{Manajemen Kinerja}

Manajemen kinerja menurut Amstrong (2006) dalam Haryono (2018) adalah sebuah proses sistematis untuk meningkatkan kinerja organisasi dengan cara mengembangkan 
kinerja individu dan team atau kelompok. Simanjuntak (2011) menjelaskan bahwa manajemen kinerja adalah seluruh kegiatan yang dilakukan untuk meningkatkan kinerja organisasi. Manajemen kinerja terdiri dari siklus yang memuat perencanaan, pembinaan dan pengembangan serta evaluasi.

Edward Deming dalam Haryono (2018) menjelaskan bahwa manajemen kinerja memiliki aktivitas utama yaitu : perencanaan, sebuah Langkah untuk mementukan apa yang akan dikerjakan; Tindakan, pelaksanaan pekerjaan untuk mewujudkan rencana yang telah disusun; pemantauan, usaha untuk memantau secara berkesinambungan terhadap rencana yang telah dibuat; penilaian, usaha untuk melakukan evaluasi terkait apa yang sudah dicapai.

Manajemen kinerja memiliki model yang terintegrasi seperti halnya dijelaskan oleh Zainal $(2014 ; 43)$ seperti gambar dibawah ini:

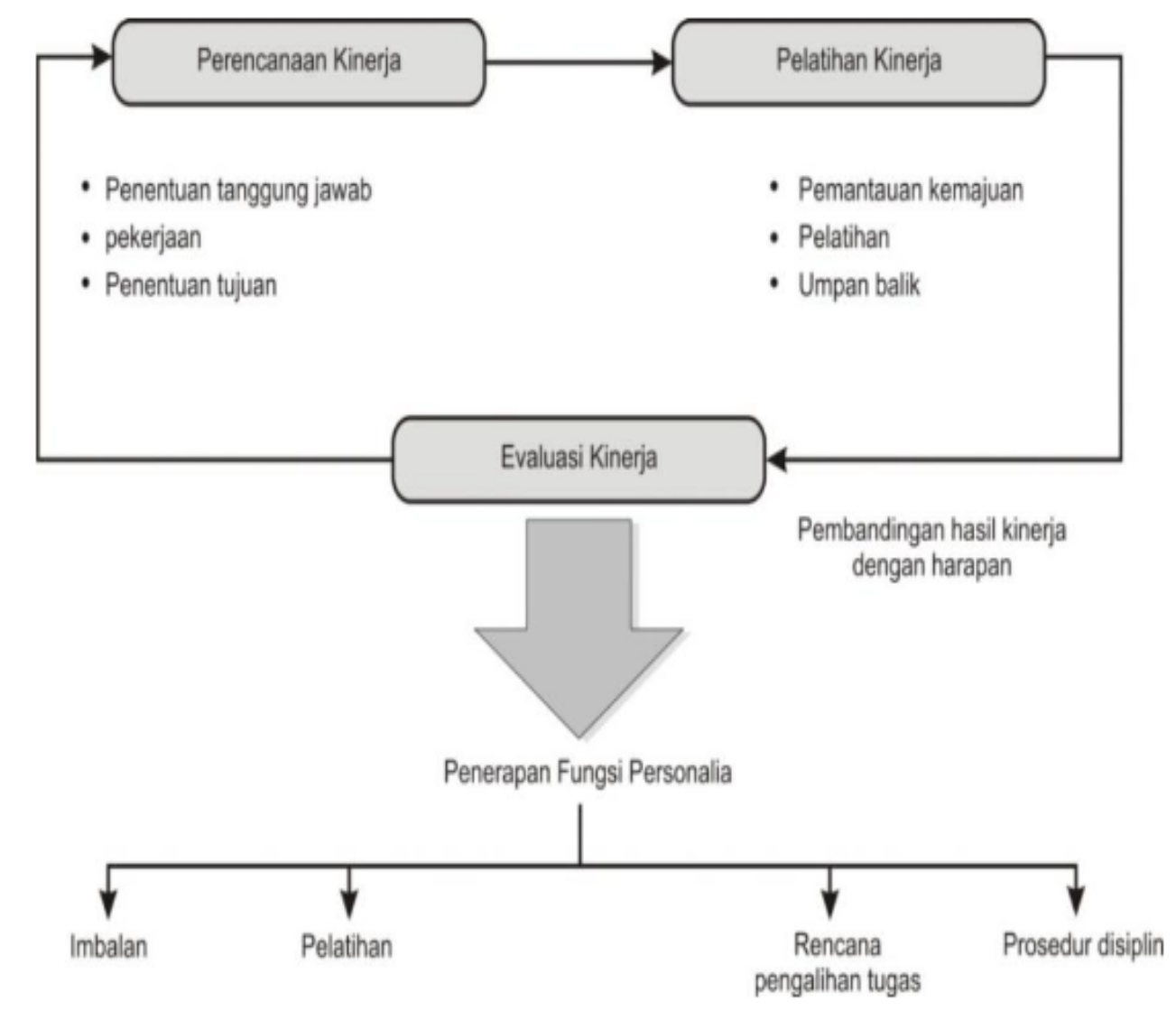

Gambar 2

Manajemen Kinerja

Sumber: Zainal (2014:43) dalam Haryono (2018) 
Samsara: " Manajemen Kinerja dalam Kerangka Flexible Working Arrangement: Pengalaman dari pelaksanaan WFH, Cascading Target Kinerja Harian"

Aktivitas diatas terdiri dari dua besaran yaitu aktivitas perencanaan dan pelatihan kinerja. Perencanaan untuk menentukan tujuan dari kinerja tersebut akan dibawa kemana. Sedangkan untuk pelatihan kinerja untuk mempersiapkan pegawai yang akan melaksanakan tujuan tersebut. Keduanya saling terhubung.

\section{Flexible Working Arrangement}

Flexible Working Arrangement merupakan bentuk alternatif pilihan yang diberikan untuk menentukan jadwal dan tempat bekerja (Rau\&Hyland dalam Simanjuntak 2019 dalam Hada, 2020). Flexible working arrangement (FWA) seperti flexytime, telecomuting, job sharing, dll (allen dalam fitriani, 2018 dalam Hada 2020). Menurut Carlson (Hada, 2020) schedule flexibility merupakan pengaturan kerja secara fleksibel dalam hal pemilihan tempat dan waktu untuk bekerja baik secara formal maupun informal. Carlson (2010) membagi schedule flexibility menjadi tiga yaitu fleksibilitas dalam menentukan waktu kerja, fleksibilitas dalam menentukan durasi waktu kerja dan fleksibilitas dalam memilih tempat kerja (Hada, 2020). Sehingga FWA dapat dipahami sebagai upaya pemberian alternatif kebebasan waktu dan tempat untuk bekerja dengan tujuan agar karyawan bertahan dan puas terhadap pekerjaannya (Hada, 2020).

Hofacker \& Konigm dalam Wicaksono 2019 menyatakan FWA memberikan fleksibilitas jam kerja dan lokasi kerja dengan harapan pegawai dapat memiliki rasa tanggung jawab dan work life balance dari pegawai (Hada, 2020). Tanggung jawab pegawai bisa dilihat dari kemampuan pegawai untuk merencanakan pekerjaan serta memenuhi target pekerjaan sesuai dengan perencanaan yang telah dibuat.

\section{Metode Penelitian}

Mini riset ini dilakukan dengan metode kualitatif dengan pendekatan deskriptif eksploratif. Sementara itu pengumpulan data dan analisis data dilakukan dengan metode desk study dengan mengumpulkan literatur yang sesuai dengan fokus penelitian. Analisis data dilakukan dengan analisis data kualitatif model interaktif.

\section{Pembahasan}

\section{Pelaksanaan Work From Home Ketika masa Pandemi Covid-19}

Pelaksanaan work from home, sebagai bagian dari antisipasi penyebaran Covid-19 memang tidak disertai dengan berbagai macam pengaturan lainnya. Beberapa peraturan masih menggunakan peraturan lama. Misalnya terkait dengan jam kerja pegawai. Masih 


\section{Jejaring Administrasi Publik, Vol. 13, No. 1, 2021, hal 1-17}

didasarkan atas jam kerja normal. Selain itu, terkait dengan absensi, masih menggunakan dasar absensi kehadiran pagi dan sore. Hal ini menandakan bahwa pelaksanaan WFH baru sebatas menggantikan lokasi tempat bekerja dari kantor ke rumah.

Selain itu, dalam pelaksanaan WFH ditemukan banyak pembelajaran diantaranya:

1. Formalisasi Kaku dalam pelaksanaan WFH

Pelaksanaan WFH yang diimplementasikan saat ini masih mengusung pola pekerjaan kantor. Pekerjaan yang dilakukan secara rutin dan terus menerus. Sehingga pelaksanaan WFH tidak ubahnya seperti bekerja di kantor namun dengan lokasi yang berbeda. Salah satunya terkait dengan rapat koordinasi. Walaupun WFH, pelaksanaan rapat koordinasi tetap berjalan seperti biasanya. Jam rutin rapat koordinasi juga maish seperti halnya pelaksanaan kerja normal. Bahkan, hal lain seperti halnya pertangungjawaban administrasi keuangan juga masih mendasarkan pada pelaksanaan kerja di kantor. Pertanggungjawaban administrasi menuntut adanya bukti kehadiran fisik virtual dan hitungan jam tertentu.

2. Target kinerja individu bias

Salah satu keunggulan dari pelaksanaan pekerjaan dari rumah atau WFH adalah target kinerja yang jelas di masing-maisng pegawai. Target kinerja in yang menjadi dasar bagi pegawai untuk menunjukkan produktivitasnya. Namun, dalam pelaksanaan WFH, sampai saat ini perubahan mengenai target kinerja individu belum sepenuhnya jelas. Target kinerja pegawai masih mendasarkan pada kehadiran dan penilaian kinerja. Bahkan dibeberapa tempat baru didasarkan atas kehadiran pegawai.

Pelaksanaan WFH juga belum mengidentifikasi jenis jabatan yang bisa melakukan pekerjaan dari rumah atau jabatan yang tidak bisa total melakukan aktivitas dari rumah. Sehingga, banyak pegawia yang tidak optimal dalam menjalankan pekerjaan dikarenakan keterbatasan sarana dan prasarana pendukung pekerjaan dari rumah. Misalnya, pekerjaan yang menuntut penggunaan aplikasi internal kantor. Aplikasi yang hanya bisa dibuka menggunakan Internet Protocol (IP) kantor.

3. Penyiapan kebutuhan sarana dan prasarana infrastruktur pendukung pelaksanaan kerja WFH

Sarana dan prasarana pendukung masih menjadi permasalahan yang krusial untuk mendukung pelaksanaan WFH. Dalam banyak kegiatan, seringkali aspek sarana dan prasarana menjadi sumber permasalahan. Misalnya ketika rapat virtual kemudian terjadi putus koneksi karena jaringan internet yang kurang stabil. Selain itu, pegawai tidak mampu mengerjakan pekerjaan karena tidak memiliki komputer. 
Samsara: " Manajemen Kinerja dalam Kerangka Flexible Working Arrangement: Pengalaman dari pelaksanaan WFH, Cascading Target Kinerja Harian"

Hal ini sangat banyak ditemui dalam pelaksanaan WFH. Apalagi jika melihat postur pegawai PNS di Indonesia yang saat ini masih banyak yang berusia sekitar 45-58 tahun. Dimana kebutuhan untuk teknologi informasi belum banyak diikuti oleh PNS di usia tersebut.

\section{Flexible Working Arrangement dalam Kerangka Peningkatan Produktivitas ASN}

Flexible Working Arrangement (FWA) merupakan sebuah konsep untuk memadukan keseimbangan antara bekerja dengan kehidupan sosial. Salah satunya dengan memberikan kebebasan ruang kerja yang tidak terbatas hanya di kantor. Namun, pelaksanaan pekerjaan bisa dimana saja. Bahkan di rumah. Selain itu, FWA juga memberikan kemandirian bagi pegawai untuk mengatur pekerjaan yang akan dilakukan. Sehingga, dalam pelaksanaan FWA target kinerja menjadi kebutuhan utama. Bukan hanya rutinitas kehadiran pegawai.

Namun, sebelum implementasi FWA, pemetaan kebutuhan jabatan yang bisa mengimplementasikan FWA dan yang tidak bisa menjadi aspek paling krusial. Hal ini dikarenakan tidak semua jabatan di organisasi pemerintah dapat mengimplementasikan FWA. Misalnya untuk satuan polisi Pamong Praja yang tugasnya harus di lapangan atau sipir penjara yang harus bertugas untuk mengamankan rumah tahanan (Rutan). Kedua jabatan tersebut sangat tidak bisa untuk menerapkan FWA dengan pengkondisian pekerjaan dilakukan secara virtual. Selain terkait jabatan, FWA juga perlu memperhatikan kebutuhan sarana dan prasarana pendukung. Berkaca pada pelaksanaan WFH, sarana dan prasarana terkait dengan teknologi informasi menjadi faktor krusial. Kelancarana pelaksanaan FWA didasarkan atas ketersediaan sarana terkait teknologi informasi.

Oleh sebab itu, sebelum implementasi FWA, analisis kebutuhan sarana infrastruktur teknologi informasi dan pemetaan kebutuhan sarana tersebut juga perlu diidentifikasi. Hal ini menjadi kebutuhan yang sangat mendasar untuk disiapkan. Khususnya agar pelaksanaan FWA bisa benar-benar sesuai dengan tujuan, bukan hanya memindahkan pekerjaan dari kantor ke rumah dan dalam pelaksanaannya terdapat banyak hambatan.

\section{Manajemen Kinerja dalam Kerangka Implementasi FWA}

Pengelolaan pekerjaan menjadi poin penting dalam pelaksanaan Flexible Working Arrangement (FWA). Hal ini dikarenakan setiap pegawai memiliki kinerja individu yang jelas dan terhubung dengan kinerja organisasi. Kinerja individu menentukan kinerja sebuah organisasi. 


\section{Jejaring Administrasi Publik, Vol. 13, No. 1, 2021, hal 1-17}

Dalam konteks manajemen sumber daya manusia, keterkaitan antara kinerja individu dengan kinerja organisasi familiar disebut dnegan manajemen kinerja. Amstrong (2006) dalam Haryono (2018) menyebutkan bahwa manajemen kinerja merupakan sebuah proses sistematis yang dijadikan sebagai pola untuk meningkatkan kinerja organisasi melalui kinerja setiap pegawai.

Manajemen kinerja menjadi pola sistematis dari perencanaan sampai evaluasi kinerja baik individu maupun organisasi. Baca (1998) membagi manajemen kinerja menjadi beberapa bagian yaitu masukan, proses, keluaran, manfaat dan feedback. Deming menyebutkan manajemen kinerja terdiri dari proses perencanaan, Tindakan, pemantauan dan penilaian. Namun, apabila dilihat dari bentuk siklu, pendapat Deming sejalan dengan Baca. Manajemen kinerja yang berbentuk sebuah pola, dapat dilaksanakan dengan sebuah siklus yang teratur. Siklus ini menurut Williams (2002) dalam Haryono saling berhubungan dan menyokong satu dengan lainnya.

Hal diatas juga sejalan dengan Peraturan Pemerintah (PP) No.30 Tahun 2019 tentang Penilaian Kinerja Pegawai Negeri Sipil. Dalam PP tersebut disebutkan bahwa system manajemen kinerja pegawai negeri sipil merupakan suatu proses sistematis yang terdiri dari perencanaan kinerja, pelaksanaan pemantauan dan pembinaan kinerja, tindak lanjut dan sistem informasi kinerja. Keseluruhan sistem ini berpola membentuk seperti siklus.

Sistem manajemen kinerja PNS diawali dari perencanaan kinerja. PP No.30 Tahun 2019 menyebutkan bahwa perencaan kinerja terdiri dari penyusunan dan penetapan Sasaran Kinerja Pegawai (SKP) dengan memperhatikan perilaku kerja. Jadi, perencanaan kinerja memuat dua besaran yaitu target kinerja dan perilaku kerja. Kedua hal yang masih saling melengkapi, apabila dilihat dari penetapan kienrja di sektor birokrasi. SKP menjadi dokumen yang wajib disusun bagi PNS disemua jabatan baik pejabat pimpinan tinggi, pejabat administrator, pengawas, fungsional maupun pelaksana. Namun, di PP No.30 2019 disebutkan bahwa masing-masing jabatan memiliki cantolan yang berbeda.

Pejabat pimpinan tinggi (JPT) Menyusun SKP dengan memperhatikan rencana strategis dan rencana kerja tahunan. Kedua dokumen ini merupakan dokumen organisasi. Sehingga peran JPT lebih banyak memberikan koordinasi. Hal yang berbeda untuk jabatan fungsional, penyusunan SKP harud didasarkan pada atasan langsung. Namun, selain itu penyusunan SKP pejabat fungsional juga memperhatikan butir kegiatan masing-masing jabatan. Masing-masing jabatan memiliki variasi yang beragam dalam penyusunan SKP. Khususnya terkait dasar penyusunan. Namun, secara keseluruhan penyusunan SKP menurut PP No.30 Tahun 2019 harus memiliki kriteria spesifik, terukur, realistis, memiliki batas 


\section{Samsara: " Manajemen Kinerja dalam Kerangka Flexible Working Arrangement:}

Pengalaman dari pelaksanaan WFH, Cascading Target Kinerja Harian"

waktu dan menyesuaikan kondisi internal dan eksternal organisasi. Kriteria ini dapat diartikan bahwa penyusunan SKP pegawai tidak berada di ruang kosong, melainkan terdpaat Batasan dan target yang jelas.

Penyusunan SKP harus terukur dalam satuan waktu. Hal ini dikarenakan, dalam pasal 26 PP No.30 Tahun 2019 disebutkan bahwa pelaksanaan kinerja harus didokumentasikan secara periodik. Pendokumentasian tersebut diantaranya mulai harian, mingguan, bulanan, triwulanan, semesteran dan tahunan. Pendokumentasian secara perioedik dipahami bahwa pelaksanaan kinerja dari perencanaan kinerja yang telah disusun diatas merupakan akumulasi. Kinerja harian yang dihasilkan akan diakumulasikan menjadi kinerja mingguan dan seterusnya. Sehingga diakhir tahun, akan terbentuk kinerja sesuai dengan perencanaan kinerja yang telah disusun dalam SKP.

Ketika pendokumentasian menuntut adanya target kinerja dari level yang lain kecil yaitu target kinerja harian maka perencanaan kinerja juga diarahkan untuk dapat mendeskripsikan perencanaan kinerja sampai level yang paling kecil yaitu perencanaan kinerja harian. Pegawai wajib untuk menjabarkan target kinerja yang termuat dalam SKP menjadi target kinerja yang lebih kecil. Target kinerja yang apabila diakumulasikan menjadi target yang lebih besar.

Penjabaran target kinerja ke tingkat yang lebih detail, walaupun tidak tercantum secara jelas di SKP, namun hal ini menjadi kebutuhan. Khususnya untuk mengukur kinerja harian. Salah satunya untuk perhitungan kinerja. Perhitungan kinerja yang dilakukan secara periodic setiap bulan, dilakukan dengan mengakumulasikan perhitungan kinerja harian dan mingguan. Hal ini sejalan dengan amanat PP No.30 tahun 2019 dalam pelaksanaan kinerja, pendokumentasiannya dilakukan secara periodik. Perhitungan kinerja periodik ini akan memudahkan dalam perhitungan prosentase kinerja bulanan. Pengukuran capaian kinerja bulanan dilakukan dnegan membandingkan target bulanan dengan akumulasi capaian target kinerja bulanan.

\section{Cascading Target Kinerja Pegawai}

Implementasi Flexible Working Arrangement (FWA) yang menekankan pada fleksibilitas kerja dengan memberikan alternatif tempat bekerja memberikan kemudahan bagi pegawai untuk menentukan tempat bekerja. Lokasi kerja bisa di kantor, rumah atau tempat lain yang dirasa cocok bagi pegawai. FWA menekankan pada kinerja output yang dihasilkan pegawai. Pegawai dituntut untuk berkinerja sama antara di kantor dengan di tempat lain. Dengan kata lain, tanggung jawab pekerjaan bukan lagi berada di pimpinan 


\section{Jejaring Administrasi Publik, Vol. 13, No. 1, 2021, hal 1-17}

sebagai penanggung jawab organisasi, melainkan di pegawai masing-masing. Pimpinan memiliki peran untuk mengordinasikan pekerjaan dan membagi pekerjaan ke seluruh pegawai sesuaui tugas dan fungsi. Pegawai yang menjalankan pekerjaan sesuai dengan tanggung jawab masing-masing. Pelaksanaan WFH memberikan banyak pengalaman dalam menjalankan pekerjaan tidak melalui kantor. Salah satunya mengenai target kinerja khususnya target kinerja harian. Hal ini yang masih menjadi problematika dalam pelaksanaan model kerja remote.

Banyak permasalahan yang masih melingkupi terkait target kinerja harian, khususnya bagi jabatan yang bisa melaksanakan pekerjaan tidak di kantor. Salah satunya identifikasi jabatan di organisasi pemerintah yang dapat melaksanakan pekerjaan secara remote belum tergambarkan secara rinci. Saat ini pelaksanaan WFH masih dilakukan untuk seluruh jabatan tanpa terkecuali. Sehingga, terdapat beberapa jabatan yang sebenarnya tidak bisa dilakukan dengan remote, juga dilakukan pekerjaan remote. Akibatnya, pegawai dnegan beberapa jabatan tidak bisa perform maksimal. Pelaksanaan pekerjaan baru bisa dilakukan ketika jadwal Work From Office (WFO).

Pekerjaan yang tidak bisa dilakukan dengan remote diantaranya administrasi keuangan. Administrasi keuangan menuntut adanya dokumen fisik yang menyebabkan pegawai harus mempersiapkan dokumen administrasi keuangan tersebut. Penyiapan dokumen ini harus dilakukan di kantor karena sarana dan prasarana yang tersedia. Sehingga, Ketika pelaksanaan WFH praktis jabatan administrasi keuangan tidak bisa bekerja secara optimal. Oleh sebab itu, pemetaan pekerjaa yang dilakukan secara remote dan fisik perlu dipetakan terlebih dahulu. Hal ini akan menjadi pijakan awal untuk menentukan perencanaan kinerja pegawai. Salah satunya terkait pembebanan pekerjaan. Pekerjaan yang dilakukan dengan remote akan mereduksi unsur kehadiran pegawai sebagai salah satu syarat kinerja. Sedangkan pekerjaan yang dilakukan dengan kehadiran di kantor masih bisa menggunakan unsur kehadiran sebagai salah satu bentuk kinerja.

Untuk pekerjaan yang dilakukan dengan remote, aspek kinerja menjadi acuan utama. Oleh sebab itu, perencanaan kinerja bukan hanya untuk menentukan target periodic tahunan. Melainkan juga sampai target harian dan mingguan. Keseluruhannya akan terakumulasi menjadi target tahunan.

Penyusunan target harian juga dilakukan dengan cascading dari target kinerja atasan langsung, target skp dan target periodik harian. Pegawai diharapkan memiliki kompetensi untuk merencanakan kinerja. Membagi pekerjaan sampai ke satuan yang paling kecil. Hal ini seperti gambar di bawah ini. 
Samsara: " Manajemen Kinerja dalam Kerangka Flexible Working Arrangement: Pengalaman dari pelaksanaan WFH, Cascading Target Kinerja Harian"

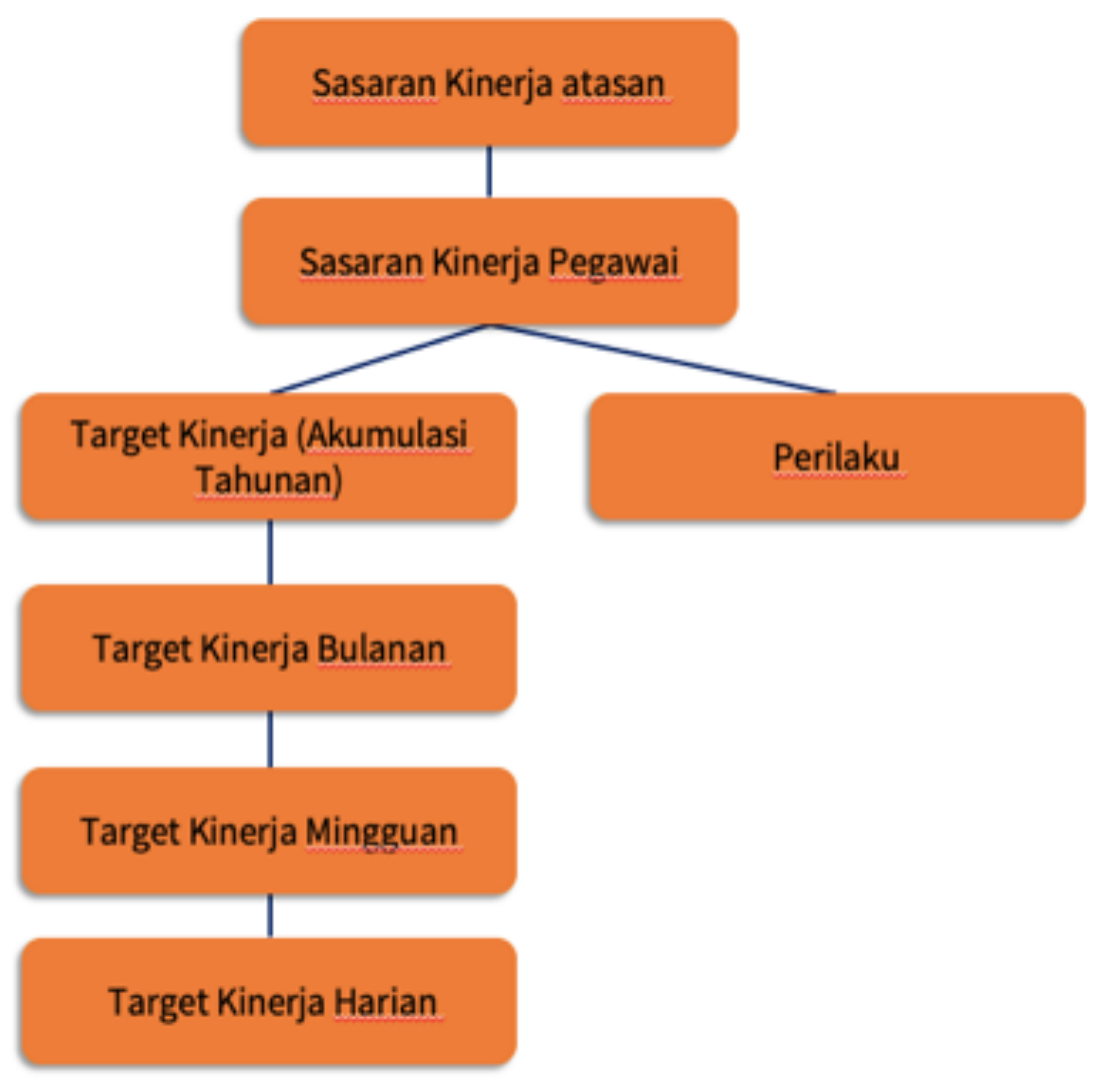

Gambar 3

Kompetensi Untuk Merencanakan Kinerja Sumber: PP No.30 Tahun 2019 tentang Penilaian Kinerja (diolah)

Gambar diatas menjelaskan bahwa cascading dari atasan langsung menjadi target kinerja pegawai dilakukan untuk memastikan target unit kerja sejalan dengan target pegawai. Target pegawai juga bervariasi. Penentuan utamanya adalah jabatan.

Pegawai dengan jabatan fungsional, memiliki target kerja sesuai dengan tugas dan fungsinya. Target kerja ini merupakan kombinasi antara target unit organisasi dan target pencapaian angka kredit (AK) jabatan fungsional.

Pegawai dengnan jabatan administrasi memiliki target kerja yang berbeda, target kinerja jabatan administrasi terbagi menjadi dua yaitu administrasi kesektreatariatan dan 
bidang sesuai dengan tugas fungsi. Hal ini juga diikuti dengan pegawai yang menduduki jabatan pelaksana.

Pegawai dnegan jabatan pelaksana, cascading target kinerja menyesuaikan dengan target kinerja pejabat administrator (koordinator) dan pengawas (sub koordinator). Masingmasing jabatan memiliki target yang berbeda. Misalnya, untuk pelaksana pengolah data, target kinerja berupa olahan data secara periodik. Pengelola arsip juga memiliki target kinerja terkait kearsipan.

\section{Penyiapan kemampuan merencanakan pegawai sebagai syarat pelaksanaan Flexible Working Arrangement}

Target kinerja pegawai tahuna menjadi output dari maisng-masing pegawai. Target ini merupakan cascading berbentuk segitiga dari atasan langsung. Setiap pegawai menjalankan satu atau lebih target kinerja atasan langsung. Target kinerja tahunan menjadi capaian akhir pegawai. Namun, dalam pelaksanaan FWA penyusunan target kerja ke bagian yang lebih detail menjadi kebutuhan tersendiri. Target kinerja untuk menjadi bukti pelaksanaan kinerja.

Pegawai dituntut untuk memiliki kemampuan merencanakan kinerja secara mandiri. Perencanaan kinerja yang terstruktur dan detail, akan menjadi kunci dalam pelaksanaan FWA. Perencanaan kinerja harian, yang nantinya akan terakumulasi menjadi pekerjaan mingguan dan bulanan akan menjadi fokus utama dalam pelaksanaan FWA. Hal ini akan menjadi dasar dan bukti bahwa pegawai telah bekerja dalam waktu tertentu. Oleh sebab itu, sebelum pelaksanaan FWA, pegawai bisa terlebih dahulu diberikan kemampuan untuk merencanakan pekerjaan. Perencanaan pekerjaan sampai ke level teknis. Misalnya terkait uraian pekerjaan mingguan dan harian.

Perencanaan pekerjaan, bukan hanya terkait dengan pekerjaan yang akan dilaksanakan, namun juga dengan alat dan bahan kerja. Alat dan bahan kerja menjadi aspek pertimbangan dalam kurun waktu tertentu pegawai bisa melakukan pekerjaan secara FWA atau bekerja dari kantor. Kompetensi merencanakan pekerjaan sampai ke level teknis akan menjadi kebutuhan bagi pegawai di seluruh jenjang jabatan. Kompetensi ini menjadi kompetensi umum, sehingga seluruh pegawai mampu untuk merencanakan kinerjanya. 
Samsara: " Manajemen Kinerja dalam Kerangka Flexible Working Arrangement: Pengalaman dari pelaksanaan WFH, Cascading Target Kinerja Harian"

\section{Kesimpulan}

Manajemen kinerja merupakan proses merencanakan kinerja sampai mengevaluasi kinerja agar target kinerja bisa dicapai dengan maksimal. Dalam proses manajemen kinerja, khususnya untuk mendukung pelaksanaan FWA, aspek perencanaan menjadi hal yang paling krusial. Pegawai dituntut untuk merencanakan kinerja pegawai sampai level yang paling teknis, pelaksanaan kinerja harian. Oleh sebab itu, sebelum pelaksanaan FWA, peningkatan kemampuan merencanakan pegawai menjadi salah satu hal yang bisa ditambahkan.

\section{Saran}

Pelaksanaan FWA perlu dibarengi dengan beberapa hal diantaranya:

1. Penekanan pada cascading target kinerja.

2. Peningkatan kompetensi pegawai khususnya dalam hal merencanakan kinerja sampai level teknis beserta kebutuhan alat kerja

3. Pembuatan aplikasi elektornik kinerja yang dapat mengukur target dan kinerja sampai ke level harian dan terakumulasi dalam kinerja periodik.

\section{Daftar Pustaka}

Hada, Reineidis Ina P, Rolland Epafras Fanggidae, Ni Putu Nursiani. (2020). Flexible Working Arrangement dan Pengaruhnya Terhadap Work Life Balance pada Resellers Online Shop. Jurnal Ekobis Vol 10 Nomor 2 Sekolah Tinggi Ilmu Ekonomi Muhammadiyah: Jakarta.

Haryono, Siswoyo. (2018). Manajemen Kinerja SDM: Teori dan Aplikasi. Luxima Metro Media: Jakarta.

Kementerian Pendayagunaan Aparatur Negara dan Reformasi Birokrasi. (2020). Arah Kebijakan Mengenai Manajemen ASN Di Masa Pandemi Covid-19. Bahan Paparan Kemenpan RB.

Osibanjo, Omotayo Adewale, Anthonia Adenji. (2012). Human Resource Management: Theory and Practice. Researchgate.

Peraturan Pemerintah Nomor 11 Tahun 2017 tentang Manajemen Pegawai Negeri Sipil

Peraturan Pemerintah Nomor 49 Tahun 2018 tentang Manajemen Pegawai Pemerintah dengan Perjanjian Kerja.

Peraturan Pemerintah Nomor 30 Tahun 2019 tentang Penilaian Kinerja PNS. 
Samsuni, (2017). Manajemen SUmber Daya Manusia. Jurnal Al-Falah Volume XVII No.31 Fakultas Syariah dan Ekonomi Islam Universitas Islam Negeri Antasari Banjarmasi Undang-Undang No. 5 Tahun 2014 tentang Aparatur Sipil Negara.

Yazdanifard, Rashad. (2014). Impact of Flexible Working Hours on Work Life Balance. American Journal of Industrial and Business Management, 